\title{
Suppression of Peripheral Blood Natural Killer Cell Activity by Excess Thyroid Hormone
}

Milivoj Papic, Joan Stein-Streilein, Margita Zakarija, J. Maxwell McKenzie, Judy Guffee, and Mary Ann Fletcher Department of Medicine, University of Miami School of Medicine, Miami, Florida 33101

\begin{abstract}
Natural killer (NK) cells were assessed in patients with hyperthyroxinemia due to Graves' disease or treatment with thyroxine $\left(\mathrm{T}_{4}\right)$. Cytolytic activity was measured with ${ }^{51} \mathrm{Cr}$-labeled $\mathrm{K562}$ tumor cells and NK enumeration was by flow cytometry using NKH-1 monoclonal antibody to identify the relevant surface marker. Activity was uniformly decreased in association with hyperthyroxinemia, regardless of the underlying pathology; however, there was no reduction in the number of $\mathrm{NKH}^{+}{ }^{+}$cells. NK activity was enhanced by addition of interleukin 2 (IL-2) in both control and patients' cells although the value in the latter instance failed to reach the basal control level. Production of IL2 by lymphocytes from hyperthyroxinemic subjects, in response to phytohemagglutinin, was also reduced. Since NK cells are thought to act as a defense against viral infections and some malignancies and may play a role in autoregulation of the immune system, this effect of $T_{4}$ may have significant biological implications.
\end{abstract}

\section{Introduction}

Human natural killer cells (NK cells) ${ }^{1}$ are a subset of lymphocytes that has attracted increasing attention in the last decade. They are characterized functionally as being, in the absence of specific antibody and without known or deliberate sensitization, spontaneously cytotoxic in vitro to a variety of cells. They are morphologically characterized as "large granular lymphocytes" (LGL) or, although there is no surface marker yet known to be unique to NK cells, they may be recognized by antibodies to membrane phenotypes. Otherwise they are quantitated by assay of their cytolytic activity. NK cells are identical or largely overlap with the population known as $\mathrm{K}$ or killer cells that lyse antibodycoated target cells $(1,2)$.

Reports relevant to an understanding of a role for NK cells in the pathogenesis of autoimmune thyroid disease include studies of K cells $(3,4)$, LGL (5), and NK cells directly by cy-

Presented in part at the 68th Annual Meeting of the Endocrine Society, Anaheim, CA, June 1986 and at the 6th International Congress of Immunology, Toronto, Canada, July 1986.

Address reprint requests to Dr. Zakarija

Received for publication 17 April 1986 and in revised form 25 September 1986.

1. Abbreviations used in this paper: $\mathrm{E} / \mathrm{T}$, effector/target ratio; IL-2, interleukin 2; LGL, large granular lymphocytes; LU, lytic units; NK, natural killer cells; PBL, peripheral blood lymphocytes; PHA, phytohemagglutinin; PTU, propylthiouracil; TSH, thyrotropin-stimulating hormone; $\mathrm{T}_{4}$, thyroxine.

J. Clin. Invest.

(c) The American Society for Clinical Investigation, Inc.

0021-9738/87/02/0404/05 \$1.00

Volume 79, February 1987, 404-408 tolytic assay $(6,7)$ or phenotypic marker $(8-10)$. Perhaps in part due to the variety of techniques used, there is a lack of uniformity of results and, specifically in hyperthyroidism, the cytolytic activity or concentration of peripheral blood $\mathrm{NK} / \mathrm{K}$ cells has been reported as higher than normal (3), normal (8), or decreased (4, $5,9)$.

In an attempt to clarify the issue we undertook the assessment of NK cell activity by cytolytic assay and number by surface marker using flow cytometry, in the blood of hyperthyroid patients with Graves' disease and in subjects being treated with thyroxine $\left(\mathrm{T}_{4}\right)$ for a variety of disorders.

\section{Methods}

The individuals from whom blood was taken for these studies were as follows: normal healthy volunteers, 27; freshly diagnosed hyperthyroid Graves' disease, 22; hyperthyroxinemic due to treatment with $\mathrm{T}_{4}, 18$. These groups will be referred to as "control," "Graves'," and "hyperthyroxinemic." The reason for $T_{4}$ therapy in the latter group of patients was treatment for Hashimoto's disease, 5, hypothyroidism after ablation therapy of Graves' disease, 5, or thyroid cancer, 3, and as suppression therapy of thyroid nodules, 5. In Table I the mean \pm SE for the ages of these subjects is given as well as the data for serum $\mathrm{T}_{4}$ and triiodothyronine $\left(T_{3}\right)$. Not all subjects of each group gave blood for tests undertaken subsequent to the initial NK cell cytolytic assays. As detailed later, 11 other individuals not fitting into the three major categories were also studied. For the NK assays, $40 \mathrm{ml}$ blood was collected between 10 a.m. and 12 noon, in heparinized vacutainer tubes, and concurrently clotted blood was taken for thyroid function tests.

Washed blood lymphocytes. Blood cells were separated from plasma by centrifugation at $400-500 \mathrm{~g}$ for $10 \mathrm{~min}$, washed with Hanks' balanced salt solution and resuspended in RPMI 1640, 5\% fetal bovine serum (FBS); effector/target ratios (E/T) were calculated assuming recovery of $10^{6}$ lymphocytes per $\mathrm{ml}$ of blood. Exact $\mathrm{E} / \mathrm{T}$ ratios were calculated using the differential and absolute lymphocyte count on each patient after the assay was completed. We have observed in nine normal human subjects that the percent lysis by washed blood in a corrected 50:1 E/T ratio was $31.5 \pm 3.8$ (SE). In the same population, using peripheral blood lymphocytes (PBL) prepared with Ficoll-Hypaque (Pharmacia Fine Chemicals, Piscataway, NJ) for the NK assay, the percent lysis was $28.3 \pm 4$.1. Therefore, we concluded that, for the NK assay, whole blood is as reliable as PBL prepared by Ficoll-Hypaque.

NK cell assay $(10,11)$. Approximately $5 \times 10^{6}$ tumor cells (K562) were labeled for $1.5 \mathrm{~h}$ with $100 \mu \mathrm{Ci} \mathrm{Na}{ }^{31} \mathrm{CrO}_{4}$ (Amersham Corp., Arlington Heights, IL) in $0.5 \mathrm{ml}$ of RPMI 1640 medium containing 5\% FBS. The cells were washed three times and diluted to a final concentration of $2 \times 10^{5}$ tumor cells/ml RPMI $1640,5 \%$ FBS, $1 \%$ penicillin/ streptomycin. Aliquots of $0.1 \mathrm{ml}$ with varying numbers of washed blood cells were placed in U-shaped wells of 96-well plastic microtiter plates (Costar, Cambridge, MA). Estimated E/T cell ratios were 12.5:1, 25:1 and 50:1. Cells at each ratio were plated in quadruplicate and plates were incubated $14 \mathrm{~h}$ at $37^{\circ} \mathrm{C}$ in $5 \% \mathrm{CO}_{2}$ and air. Spontaneous ${ }^{51} \mathrm{Cr}$ release was determined by incubating target cells in culture medium alone. Maximum releasable counts were determined by adding detergent (Zap-oglobin II, Coulter Diagnostics, Hialeah, FL) to the wells. After incubation, plates were centrifuged at $400 \mathrm{~g}$ for $5 \mathrm{~min}$ and $0.1 \mathrm{ml} \mathrm{su}-$ pernatant was removed and counted in a gamma well counter (LKB- 
Table I. Clinical Data

\begin{tabular}{llcl}
\hline Group & Age & $\mathrm{T}_{4}$ & $\mathrm{~T}_{3}$ \\
\hline$n$ & $y r$ & $\mu g / d l$ & $n g / d l$ \\
Control (27) & $41 \pm 14^{*}$ & $7.6 \pm 0.2$ & $150 \pm 3$ \\
Graves' (22) & $37 \pm 15$ & $18.9 \pm 1.5^{\ddagger}$ & $424 \pm 44^{\ddagger}$ \\
Hyperthyroxinemic (18) & $45 \pm 17$ & $13.5 \pm 1.1^{\ddagger}$ & $172 \pm 11^{8}$
\end{tabular}

* Mean \pm SE.

$P$ vs. control: ${ }^{\ddagger}<0.001,{ }^{\S}<0.01$.

Produkter AB, Bromma, Sweden). Cytotoxicity was expressed in lytic units [LU $(20 \%) / 10^{6}$ ] as described by Pross and Maroun (12); the calculation results in numbers directly proportional to the effector cell activity.

Interleukin 2 (IL-2) augmentation of $N K$ cell activity $(13,14)$. To test whether NK activity could be augmented with IL-2, blood cells were incubated with $150 \mathrm{U}$ of partially purified IL-2 (Meloy Laboratories, Springfield, VA) per $\mathrm{ml}$ for $24 \mathrm{~h}$ at $37^{\circ} \mathrm{C}$ before adding target cells.

Production of IL-2 by PBL after phytohemagglutinin (PHA) stimulation (15). Washed blood cells were resuspended at $10^{7} / \mathrm{ml}$ RPMI, $20 \%$ FBS. PHA (Pharmacia Fine Chemicals), $0.1 \mathrm{mg} / \mathrm{ml}$ was added to 5-7 $\mathrm{ml}$ cells in T-25 flasks and incubated for $3 \mathrm{~d}$ at $37^{\circ} \mathrm{C}$ in $5 \% \mathrm{CO}_{2}$ and air. The cells were sedimented by centrifugation $(300 \mathrm{~g}, 10 \mathrm{~min})$ and the supernatant filtered and stored at $-20^{\circ} \mathrm{C}$ for testing of IL-2 activity.

$I L-2$ assay $(15,16)$. Supernatants were diluted serially from 1:1 to 1:4,096 across a 96-well microtiter plate. To each well $10^{4} \mathrm{HT} 2$ cells, an IL-2 dependent mouse $\mathrm{T}$ cell line, were added. The plates were incubated for $20 \mathrm{~h}$ at $37^{\circ} \mathrm{C}$ in $5 \% \mathrm{CO}_{2}$ and air. The cells were pulsed with $0.5 \mu \mathrm{Ci}$ $\left[{ }^{3} \mathrm{H}\right]$ thymidine (New England Nuclear, Boston, MA) per well. $4 \mathrm{~h}$ later, using a cell harvester, the plates were harvested onto filters that were dried and placed in vials to which $1 \mathrm{ml}$ of Aquasol II (New England Nuclear) was added. The standard values were those obtained using a preparation containing a known concentration of IL-2. Control counts were those observed with HT2 cells without IL-2. The percent standard was calculated as follows: Percent standard = experimental - control/ standard - control $\times 100$. The results were subjected to probit analysis to determine the dilution of IL-2 that supported $50 \%$ of standard proliferation of HT2 cells. This factor 50 for known IL-2 was arbitrarily designated as one unit of IL-2 activity.

Enumeration of NK cells (17). Monoclonal antibody NKH-1 (Coulter Immunology, Hialeah, FL) was used as a surface marker. Stained specimens were run on a flow cytometer (Epics C, Coulter Electronics, Hialeah, FL) for quantitation of percent positive cells as described in detail elsewhere (17).

$\mathrm{T}_{4}$ and $\mathrm{T}_{3}$ assays were carried out in our Clinical Thyroid Laboratory by ARIA II (Becton Dickinson Immunodiagnostics, Salt Lake City, UT); normal values are 4.5-10 $\mu \mathrm{g} / \mathrm{dl}$ and $90-200 \mathrm{ng} / \mathrm{dl}$, respectively. Statistical evaluations used included Student's $t$ test, and discriminant analysis with application of Box's " $M$ " test (18).

\section{Results}

Illustrative data, expressed as percent lysis, for three ratios of E/ $T$, are given in Table II. When the individual NK cell cytolytic activity (as lytic units) for all subjects in the three main groups studied was compared, there was a highly significant reduction with cells from both the Graves' and hyperthyroxinemic subjects (Fig. 1). Mean \pm SE were 15.4 $\pm 2.1,1.2 \pm 0.4$, and $1.2 \pm 0.3$, for the control, Graves', and hyperthyroxinemic groups, respectively.

Details of 11 other patients whose NK cell activity was assayed but who did not fit into the groupings used in Table I and Fig. 1 are listed in Table III. Patients $1-4$ had low NK activity
Table II. Summary of NK Activity

\begin{tabular}{llrr}
\hline & \multicolumn{3}{l}{ Percent lysis* at E/T ratio } \\
\cline { 2 - 4 } Group & \multicolumn{1}{l}{$10: 1$} & \multicolumn{1}{c}{$25: 1$} & \multicolumn{1}{c}{$50: 1$} \\
\hline$n$ & & & \\
Control (27) & $6.7 \pm 0.9^{\ddagger}$ & $15.1 \pm 1.7$ & $26.2 \pm 2.3$ \\
Graves' (22) & $0.5 \pm 0.2$ & $1.3 \pm 0.4$ & $2.6 \pm 0.8$ \\
Hyperthyroxinemic (18) & $0.6 \pm 0.2$ & $1.4 \pm 0.4$ & $2.8 \pm 0.8$ \\
\hline
\end{tabular}

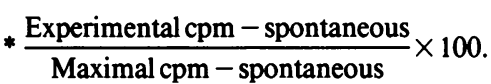

Patient groups vs. control, for all ratios, $P<0.001$.

${ }^{\ddagger}$ Mean \pm SE.

with a low or normal $\mathrm{T}_{4}$ concentration but all had a high serum $T_{4}$ value documented 1-2 mo previously. Patient 5 had received ${ }^{131}$ I therapy 3 mo previously and had been maintained euthyroid on propylthiouracil (PTU) thereafter; he had a normal $\mathrm{T}_{4}$ concentration and normal cytolytic activity. Patient 6 , after 1 wk of $\mathrm{T}_{4}$ therapy for hypothyroidism, had normal cytolytic activity; 7 and 8 were hypothyroid as a result of treatment, 7 for Graves' disease and 8 for carcinoma, and had normal NK activity. Patient 9 had low activity and a high $T_{4}$ concentration resulting from silent thyroiditis of at least 8 wk duration. Patients 10 and 11 were, respectively, 5 and $1.5 \mathrm{yr}$ on antithyroid drug therapy, although serum $\mathrm{T}_{4}$ concentration, in both, was high at the time blood was taken for NK assay; because of histories of noncompliance, it is uncertain for how long that had been the case. In summary, the data from these 11 patients support the hypothesis that NK cell activity in the PBL reflects more the $T_{4}$ concentration of the preceding few weeks than the value obtained coincident with the cytolytic assay. Our data do not permit a precise definition of the time required to effect the presumed change in NK cell activity.

For all subjects whose data are shown in Fig. 1, discriminant analysis of NK cell activity versus $\mathrm{T}_{4}$ concentration was calculated and, by Box's $M$ test, a highly significant $(P<0.001)$ result was obtained; this indicated that the patients' data and controls represented two distinct populations (Fig. 2). There was no such finding with serum $T_{3}$ concentration. It should be noted that

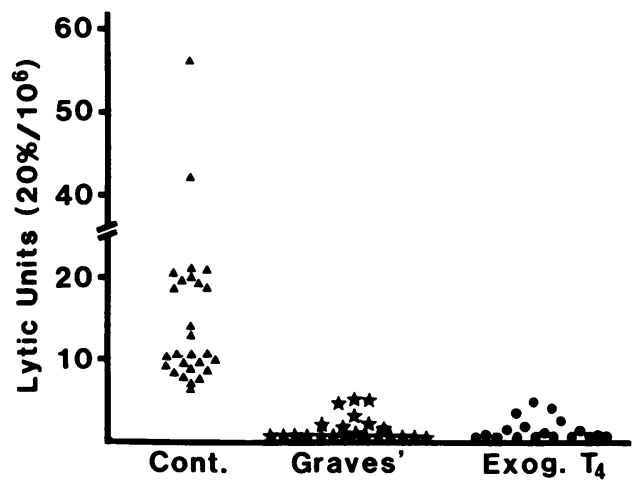

Figure 1. NK cell activity of PBL. On the abscissa the donors of the cells are identified as control (Cont.), Graves' and hyperthyroxinemic (Exog. $T_{4}$ ). The number of subjects in each group is given in Table $I$. Each dot represents the mean LU for an individual's NK cells as described in Methods. 
Table III. NK Activity in 11 Miscellaneous

Patients with Thyroid Disease

\begin{tabular}{llcc}
\hline & Therapy & $\mathrm{T}_{4}$ & Lytic units \\
\hline & & $\mu \mathrm{g} / \mathrm{dl}$ & $20 \% / 10^{6}$ \\
& & 5.8 & 0.5 \\
Thyroidectomy for Graves' & $\mathrm{T}_{4}$ & 8.9 & 3.5 \\
Hashimoto's & $\mathrm{T}_{4}$ & 9.7 & 1.0 \\
Graves' & PTU & 2.5 & 3.6 \\
Thyroidectomy for Graves' & NIL & 4.3 & 21.8 \\
Graves' & PTU & 8.0 & 17.1 \\
Hashimoto's & $\mathrm{T}_{4}$ & 1.0 & 25.5 \\
Graves' & Methimazole & & \\
Thyroidectomy for & & 4.0 & 20.2 \\
$\quad$ carcinoma & NIL & & \\
Silent thyroiditis; 2 mo & & 16.2 & 1.2 \\
$\quad$ duration & NIL & 17.9 & 9.1 \\
Graves' & PTU & 17.0 & 15.2 \\
Graves' & PTU & & \\
\hline
\end{tabular}

For details, see Methods.

serum $\mathrm{T}_{3}$ concentration was above normal in every Graves' patient (one had $T_{3}$-thyrotoxicosis and $T_{4}$ of $7.5 \mu \mathrm{g} / \mathrm{dl}$ ), but was in the normal range for all but two of the hyperthyroxinemic patients. However, serum $\mathrm{T}_{3}$ was higher in the latter group than in the control subjects (Table I).

Low NK activity could be due to an inability of NK cells to respond to regulatory lymphokines such as IL-2. Therefore, the ability of NK cells to respond in vitro to IL-2 was tested with blood obtained from the control, Graves' and hyperthyroxinemic subjects and the data are depicted in Fig. 3. Although there was a highly significant increase in cytolytic activity in response to IL-2 in all groups, the absolute values for the lysis of ${ }^{51} \mathrm{Cr}-\mathrm{K} 562$ target cells after IL-2 addition was much less for the 2 patient groups than for the activity exhibited by the controls. The aug-

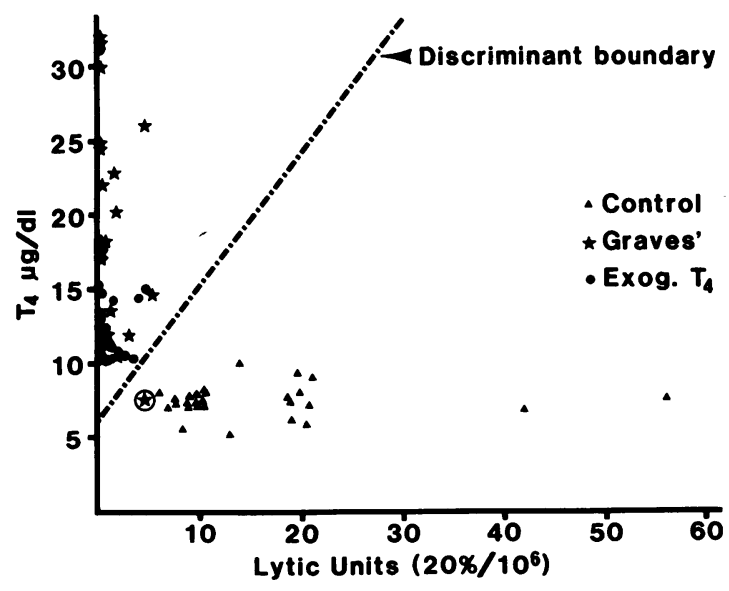

Figure 2. Scatterplot of NK activity of PBL versus serum $\mathrm{T}_{4}$ concentration. Each dot represents the values obtained with blood from the individuals whose NK activity is indicated in Fig. 1. Discriminant analysis provided the following function: $F\left(T_{4}, L U\right)=0.803$ $-0.119^{*} T_{4}+0.105^{*} \mathrm{LU}$. The diagonal interrupted line is the resulting discriminant boundary. Values are thus classified as two populations $[P<0.001$ by Bcx's M test (18)] with only one value (circled) wrongly classified; this patient, referred to in the text, had $\mathrm{T}_{3}$-thyrotoxicosis with a serum $\mathrm{T}_{4}$ of $7.5 \mu \mathrm{g} / \mathrm{dl}$.

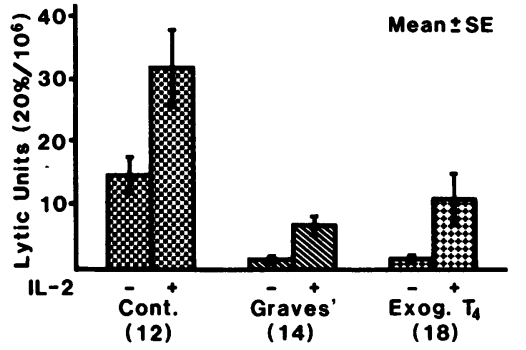

Figure 3. Effect of IL-2 on NK activity of PBL. Blood cells from $(n)$ individuals in the three groups identified (Cont. $=$ control; Exog. $T_{4}$ $=$ hyperthyroxinemic) were incubated with or without $150 \mathrm{U}$ of partially purified IL-2 per $\mathrm{ml}$ for $24 \mathrm{~h}$ before adding target cells (see text for details). There was a significant response ( $P$ $<0.001$ ) in every instance but the augmented activity in the Graves' patient group remained less than that observed with unstimulated control cells $(P<0.001)$.

mented NK activity of the majority of patients' cells remained below the range of unstimulated normal values that were obtained in this experiment or as shown in Fig. 1.

The action of $T_{4}$ to lower NK cell activity could be by affecting $\mathrm{T}$ cell secretion of NK-regulating molecules such as IL2. Therefore the capacity of $T$ cells to secrete IL-2 in vitro was tested by the addition of PHA that can trigger the release of IL2 from T cells. In the IL-2 assay described in Methods less IL2 was produced by cells from both patient groups as compared with that released by PBL from control subjects (Table IV).

In an attempt to establish whether the loss of NK activity reflected a reduction in the number of cells we counted cells by flow cytometry, using the surface marker NKH-1. The results, shown in Table $\mathrm{V}$, indicate that hyperthyroxinemia was not associated with a decrease in the concentration of $\mathrm{NKH}-1^{+}$cells.

\section{Discussion}

Our data indicate that the functional activity of human NK cells is depressed by chronic supranormal concentrations of $T_{4}$, whether the hormone is of endogenous or exogenous origin. The functional abnormality may lie in an impaired ability of $T$ cells to secrete IL-2 and/or the impaired ability of NK cells to respond to IL-2. This lymphokine is known to have a role in the regulation of NK cell activity but is not the only factor involved $(1,2)$ so our studies do not lend themselves to more than a general speculation of mechanisms underlying this consequence of $\mathrm{T}_{4}$ excess; for instance we do not know if the action is direct or indirect, although the absolute number of NK cells appears to be normal. Nonetheless, the consistency of the depression of NK cell activity in Graves' disease and other hyperthyroxinemic states, and the statistical evidence that NK activity in patients with a high con-

Table IV. PHA Stimulation of IL-2 Production

\begin{tabular}{ll}
\hline Group & IL-2 \\
\hline$n$ & $U / m l$ \\
Control (9) & $8.79 \pm 0.20^{*}$ \\
Graves' (7) & $2.23 \pm 0.41$ \\
Hyperthyroxinemic (16) & $3.04 \pm 0.37$
\end{tabular}

Both the Graves' and hyperthyroxinemic groups' values were significantly less than control: $P<0.001$.

* Mean \pm SE. 
Table V. Enumeration of NK cells

\begin{tabular}{ll}
\hline Group & $\mathrm{NKH}-\mathrm{I}^{+}$cells: absolute number $/ \mathrm{mm}^{3}$ \\
\hline$n$ & \\
Control (13) & $207 \pm 31^{*}$ \\
Hyperthyroxinemic (16) & $297 \pm 53$ \\
Normal or low $\mathrm{T}_{4}(12)$ & $163 \pm 18$ \\
\hline
\end{tabular}

Both patient groups were not significantly different from the control. * Mean \pm SE.

centration of $T_{4}$ is significantly lower than normal, merit consideration of the biological consequences of such a finding.

There is growing evidence that NK cells may have a role to play in controlling the development and dissemination of certain malignancies $(1,2)$. This concept is the basis of the recently reported attempts to manage metastatic disease by treating a patient's PBL with IL-2 in vitro, and so developing lymphokineactivated killer cells, before returning them to the donor (18). However, the evidence for a correlation between NK activity and tumor spread is best with one malignancy, namely melanoma $(20,21)$, and the data related to other forms of neoplasia remain variable and inconclusive $(1,2)$.

Similarly there is evidence that NK cells enhance resistance to viral infections. This is based upon in vitro studies showing, for instance, that NK cells preferentially lyse virus-infected cells $(22,23)$ and the fact that chronic in vivo virus infection in mice may be associated with persistently increased NK cell activity (24). Also it was shown that NK-depleted mice succumbed to influenza virus infection more readily than did control mice (25). Yet it must be admitted that there are no convincing data in man linking virus susceptibility with reduced NK cell activity.

While there is no recognized increased incidence of either malignancy or viral infection in patients with Graves' disease, we have been unable to find a specific study excluding the possibility; there also are no studies related solely to hyperthyroxinemia per se. We do not yet have longitudinal studies in individuals proving the reversibility of the suppressive effect on NK cells; however, such a possibility is suggested by the NK activity of patients' cells shown in Table III. Consequently, it might be that the relatively short-lived influence of hyperthyroidism of Graves' disease (assuming the great majority of patients are recognized and treated appropriately) may be less likely to have an effect than will hyperthyroxinemia from $\mathrm{T}_{4}$ therapy that is commonly life-long once initiated. A replacement daily dose of $T_{4}$ to treat hypothyroidism may range from $0.1 \mathrm{mg}$ or less to 0.2 mg or more, all of which may result in the serum $T_{4}$ concentration being above normal. It is conventional to see the high $T_{4}$, with normal serum $T_{3}$ concentration, as acceptable since there are no clinical features of hyperthyroidism $(26,27)$. Perhaps, in view of the depressed NK activity we have observed, this attitude should be reevaluated. Moreover, in the treatment of thyroid cancer it is common to prescribe, after tumor ablation, a supraphysiological dose of $T_{4}$ to ensure complete suppression of thyroid-stimulating hormone (TSH). This is another life-long maneuver and it may be that, especially with the availability of recently developed ultrasensitive assays for TSH, the dose of $T_{4}$ should specifically be the minimum to effect TSH suppression as documented by appropriate testing.
Another postulated role for NK cells is in immunoregulation $(1,2)$. This is in part because of the recognized ability of NK cells to interact with other immune cells (28) and to secrete lymphokines such as interferon and IL-2, which have immunoregulatory functions. In this regard there have been considerations that alteration in NK cell activity might be a factor in the perpetuation of Graves' disease $(4,5,9)$. This concept rests on the implication that NK cells (9) [or K cells (4) or LGL (5)] might specifically control the B cells responsible for production of the thyroid-stimulating antibody of Graves' disease (28) and a reduction in cytolytic activity might allow perpetuation of $B$ cell activation. This is a viewpoint that will require considerably more data for validation and acceptance.

To turn to other reports of NK cells in Graves' disease, our results are in agreement with some but not with others. $\mathrm{K}$ cells, measured as antibody-dependent cell-mediated cytotoxicity, were found to be normal in thyrotoxic Graves' disease by one group (3) but reduced as quantitated by another $(4,5,9)$. Amino (4) and Iwatani (5) and their colleagues identified reduced NK/ $\mathrm{K}$ cell numbers in Graves' disease, with an increase in Hashimotos' disease, and a significant negative correlation with $T_{4}$ concentration when both diagnostic groups were combined; quantitation was by a plaque-forming technique (4) and by enumeration of LGL cells (5). Using the antibody Leu-7, that may be a specific antibody to NK cells $(1,2)$, Amino et al. recently reported in abstract (9) data comparable to those they obtained with the other procedures $(4,5)$. However, uniformly, with all these techniques, the Japanese workers found an actual increase in $\mathrm{NK} / \mathrm{K}$ cells in "destructive thyrotoxicosis," i.e., hyperthyroidism resulting from thyroiditis $(4,5,9)$. These findings cannot at present be reconciled with ours in terms of either assessed $\mathrm{NK}$ activity or the absolute numbers we estimated as $\mathrm{NKH}-1^{+}$ cells. As far as quantitating NK cells is concerned, however, certain reservations must be retained. Cells that mediate cytotoxicity to K562 have a variety of surface phenotypes. Thus, while cells expressing NKH-1 may not change in numbers, a subset of NK cells may change (within or outside the NKH- ${ }^{+}$ population). As reported by Lanier et al. (30) within the NKH1 cell population there are three subsets: $(a) \mathrm{CD}^{-} \mathrm{CD}^{-} 6^{+}$Leu$19^{+}$; (b) $\mathrm{CD}^{+} \mathrm{CD}^{-} 6^{-}$Leu-19 ${ }^{+}$, (c) $\mathrm{CD}^{-} \mathrm{CD}^{-} 6^{-}$Leu-19 bright ${ }^{+}$. Thyroid hormone could have an effect on any of these subpopulations. For instance, in the above-referenced paper cytotoxic activity of $\mathrm{CD}^{+} \mathrm{CD}^{-} 6^{-}$Leu- $19^{+}$was significantly lower than $\mathrm{CD}^{-} \mathrm{CD}^{-} 6^{+}$Leu-19+ ${ }^{+} \mathrm{NK}$ cells. Thus a shift from CD3$\mathrm{CD} 6^{+} \mathrm{Leu}-19^{+}$to $\mathrm{CD}^{+} \mathrm{CD} 16^{-}$Leu- $19^{+}$cells in the peripheral blood would affect NK activity without affecting the number of Leu- $19^{+}$cells. We therefore consider our data on NK cell numbers in the peripheral blood as preliminary.

In summary, we found decreased NK cell activity, in the peripheral blood of patients, related to $T_{4}$ concentration, rather than to the diagnosis of Graves' disease. It has still to be firmly established whether this reflects reduced cytolytic activity per NK cell, or a deficiency of the absolute number of involved cells, in view of the uncertainty surrounding indentification of the cell that provides the cytolytic activity. Furthermore, discrepancies from other studies using related but not identical techniques have to be clarified, as have the biological implications of these findings.

\section{Acknowledgments}

We wish to thank Dr. Hugh Pross (Kingston, ON) for his generous gift of computer software for calculating lytic units and for his helpful advice. 
Appreciation is expressed to Mrs. Gilda Manicourt for typing the manuscript. Dr. J. M. McKenzie is the Kathleen and Stanley Glaser Professor of Medicine.

Supported by U. S. Public Health Service grants HL-33372 and AM31391.

\section{References}

1. Trinchieri, G., and B. Perussia. 1984. Human natural killer cells: biologic and pathologic aspects. Lab. Invest. 50:489-513.

2. Ortaldo, J. R., and R. B. Herberman. 1984. Heterogeneity of natural killer cells. Annu. Rev. Immunol. 2:359-394.

3. Calder, E. A., W. J. Irvine, N. M. Davidson, and F. Wu. 1976. T, $\mathrm{B}$ and $\mathrm{K}$ cells in autoimmune thyroid disease. Clin. Exp. Immunol. 25: 17-22.

4. Amino, N., H. Mori, Y. Iwatani, S. Asari, Y. Izumiguchi, and K. Miyai. 1982. Peripheral K lymphocytes in autoimmune thyroid disease: decrease in Graves' disease and increase in Hashimoto's disease. J. Clin. Endocrinol. Metab. 54:587-591.

5. Iwatani, Y., N. Amino, O. Kabutomori, H. Mori, H. Tamaki, S. Motoi, Y. Izumiguchi, and K. Miyai. 1984. Decrease of peripheral large granular lymphocytes in Graves' disease. Clin. Exp. Immunol. 55:239244.

6. Bogner, U., J. R. Wall, and H. Schleusener. 1985. Direct lymphocytotoxicity in autoimmune thyroid disease. Proceedings of the 9th International Thyroid Congress, Sao Paulo, October 1985, 168 (Abstr.).

7. Del Prete, G. F., E. Maggi, S. Mariotti, A. Tiri, D. Vercelli, P. Parronchi, D. Macchia, A. Pinchera, M. Ricci, and S. Romagnani. 1986. Cytolytic T lymphocytes with natural killer activity in thyroid infiltrate of patients with Hashimotos' thyroiditis: analysis at clonal level. J. Clin. Endocrinol. Metab. 62:52-57.

8. Wall, J. R., R. Baur, H. Schleusener, and P. Bandy-Dafoe. 1983. Peripheral blood and intrathyroidal mononuclear cell populations in patients with autoimmune thyroid disorders enumerated using monoclonal antibodies. J. Clin. Endocrinol. Metab. 56:164-169.

9. Amino, N., M. Aozasa, H. Tamaki, J. Tachi, Y. Watanabe, 'Y. Iwatani, S. Fujiyasu, M. Nasu, M. Mori, and O. Tanizawa. 1985. Peripheral natural killer (NK) lymphocytes in autoimmune thyroid disease. Proceedings of the 9th International Thyroid Congress, Sao Paulo, October 1985, 187 (Abstr.).

10. Ottenhof, P. C., A. Morales, and M. G. Baines. 1981. Quantitation of a whole blood assay for human natural killer cell activity. J. Immunol. Methods. 42:305-318.

11. Stein-Streilein, J., M. Bennett, D. Mann, and V. Kumar. 1983. Natural killer cells in mouse lung: surface phenotype, target preference, and response to local influenza virus infection. J. Immunol. 131:26992704.

12. Pross, H. F., and J. A. Maroun. 1984. The standardization of NK cell assays for use in studies of biological response modifiers. $J$. Immunol. Methods. 68:235-249.

13. Rabin, H., R. F. Hopkins III, F. W. Ruscetti, R. H. Neubauer, R. L. Brown, and T. G. Kawakani. 1956. Spontaneous release of a factor with properties of $\mathrm{T}$-cell growth factor from a continuous line of primate tumor T-cells. J. Immunol. 127:1852-1856.

14. Pinkston, P., P. B. Bitterman, and R. G. Crystal. 1983. Spon- taneous release of interleukin-2 by lung T-lymphocytes in active pulmonary sarcoidosis. N. Engl. J. Med. 308:793-800.

15. Gillis, S., M. M. Ferm, W. Ou, and K. A. Smith. 1978. T cell growth factor: parameters of production and quantitative microassay for activity. J. Immunol. 120:2027-2032.

16. Oppenheim, J. J., and B. Schecter. 1976. Lymphocyte transformation. In Manual of Clinical Immunology. N. Rose, and H. Friedman, editors. American Society for Microbiology, Washington, D.C. 81-94.

17. Fletcher, M. A., G. C. Baron, M. R. Ashman, M. A. Fischel, and N. G. Klimas. The use of whole blood methods in assessment of immune parameters in immunodeficiency states. Diagnostic Immunol. In press.

18. Morrison, D. F. 1967. Multivariate Statistical Methods. McGrawHill Book Co., New York.

19. Rosenberg, S. A., M. T. Lotze, L. M. Muul, S. Leitman, A. E. Chang, S. E. Ettinghausen, Y. L. Matory, J. M. Skibber, E. Shiloni, J. T. Vetto, C. A. Seipp, C. Simpson, and C. M. Reichert. 1985. Observations on the systemic administration of autologous lymphokine-activated killer cells and recombinant interleukin-2 to patients with metastatic cancer. N. Engl. J. Med. 313:1485-1492.

20. Hersey, P., A. Hobbs, A. Edwards, W. H. McCarthy, and V. J. McGovern. 1982. Relationship between natural killer cell activity in histological features of lymphocyte infiltration and partial regression of the primary tumor in melanoma patients. Cancer Res. 42:363-368.

21. Hersey, P., A. Edwards, M. Honeyman, and W. H. McCarthy. 1979. Low natural killer-cell activity in familial melanoma patients and their relatives. Br. J. Cancer. 40:113-122.

22. Santoli, D., G. Trinchieri, and F. S. Lief. 1978. Cell-mediated cytotoxicity against virus-infected cells in humans. 1. Characterization of the effector lymphocyte. J. Immunol. 121:526-531.

23. Yasukawa, M., and J. M. Zarling. 1983. Autologous herpes simplex virus-infected cells are lysed by human natural killer cells. J. Immunol. 131:2011-2016.

24. Bukowski, J. F., C. A. Biron, and R. M. Welsh. 1983. Elevated natural killer cell-mediated cytotoxicity, plasma interferon, and tumor cell rejection in mice persistently infected with lymphocytic choriomeningitis virus. J. Immunol. 131:991-996.

25. Stein-Streilein, J., and J. Guffee. 1986. In vivo treatment of mice and hamsters with antibodies to asialo GM1 increases morbidity and mortality to pulmonary influenza infection. J. Immunol. 136:1435-1441.

26. Salmon, D., M. Rendell, J. Williams, C. Smith; D. A. Ross, J. M. Waud, and J. E. Howard. 1982. Chemical hyperthyroidism. Arch. Intern. Med. 142:571-573.

27. Ingbar, J. C., M. Borges, S. Iflah, R. E. Kleinmann, L. E. Braverman, and S. H. Ingbar. 1982. Elevated serum thyroxine concentration in patients receiving "replacement" doses of levothyroxine. J. Endocrinol. Invest. 5:77-85.

28. Hansson, M., R. Kiessling, and B. Andersson. 1981. Human fetal thymus and bone marrow contain target cells for natural killer cells. Eur. J. Immunol. 11:8-12.

29. Zakarija, M., J. M. McKenzie, and K. Banovac. 1980. Clinical significance of assay of the thyroid-stimulating antibody of Graves' disease. Ann. Intern. Med. 93:28-32.

30. Lanier, L. L., A. M. Le, C. İ. Civin, M. R. Loken, and J. H. Phillips. 1986. The relationship of CD16 (Leu-11) and Leu-19 (NKH1) antigen expression on human peripheral blood NK cells and cytotoxic T lymphocytes. J. Immunol. 136:4480-4486. 